\title{
Dietary Supplementation with Fumaric Acid Improves Growth Performance in Nile Tilapia Juveniles
}

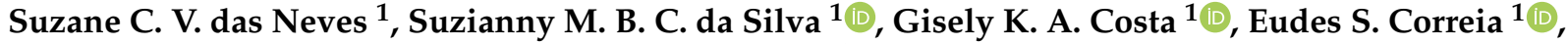 \\ Alexandre L. Santos ${ }^{2}$ (D) Lilian C. R. da Silva ${ }^{2}$ (D) and Álvaro J. A. Bicudo ${ }^{2, *(D)}$ \\ 1 Departamento de Pesca e Aquicultura, Universidade Federal Rural de Pernambuco, Dois Irmãos, \\ Recife 52171-900, PE, Brazil; suvarela.pesca@hotmail.com (S.C.V.d.N.); suzianny.silva@ufrpe.br (S.M.B.C.d.S.); \\ gisely.costa01@gmail.com (G.K.A.C.); escorreia@uol.com.br (E.S.C.) \\ 2 Departamento de Zootecnia, Universidade Federal do Paraná-Rua Pioneiro, 2153, \\ Palotina 85950-000, PR, Brazil; aleseur@gmail.com (A.L.S.); lcrsilva@ufpr.br (L.C.R.d.S.) \\ * Correspondence: ajabicudo@gmail.com
}

check for updates

Citation: das Neves, S.C.V.; da Silva, S.M.B.C.; Costa, G.K.A.; Correia, E.S.; Santos, A.L.; da Silva, L.C.R.; Bicudo, Á.J.A. Dietary Supplementation with Fumaric Acid Improves Growth Performance in Nile Tilapia Juveniles. Animals 2022, 12, 8. https://doi.org/ 10.3390/ani12010008

Academic Editors: Miquel Planas Oliver and Ike Olivotto

Received: 11 November 2021 Accepted: 17 December 2021 Published: 21 December 2021

Publisher's Note: MDPI stays neutral with regard to jurisdictional claims in published maps and institutional affiliations.

Copyright: (C) 2021 by the authors. Licensee MDPI, Basel, Switzerland. This article is an open access article distributed under the terms and conditions of the Creative Commons Attribution (CC BY) license (https:/ / creativecommons.org/licenses/by/ $4.0 /)$.
Simple Summary: The benefits of dietary supplementation with organic acids are commonly known in farm animals, especially swine and poultry, but these compounds are rarely exploited as additives to aquafeeds. Fumaric acid (FA) and its salts are among the most used organic acids in terrestrial animal feeds, but research with fish diets is limited. This study evaluated the inclusion of FA $(0,5$, $10,15,20$, and $30 \mathrm{~g} / \mathrm{kg}$ ) in the diets of Nile tilapia juveniles, and showed that supplementation improved growth, feed efficiency, protein use, and intestinal villi morphometry. Additionally, the population of undesirable intestinal bacteria was reduced (Gram-negative) or eliminated after 28 days (Enterobacteriaceae) in fish fed fumaric acid diets. Therefore, this study supports the addition of fumaric acid to the diet as a reliable strategy to improve the production and intestinal microbiota health of Nile tilapia juveniles.

\begin{abstract}
Organic acids have recently been identified as promising replacements for antibiotics in aquafeeds that promote fish growth and feed efficiency. This study evaluated the inclusion of fumaric acid (FA; 0, 5, 10, 15, 20, and $30 \mathrm{~g} / \mathrm{kg}$ ) in diets (350 g/ kg CP; $3.4 \mathrm{kcal}$ digestible energy/g) of Nile tilapia juveniles. Fish (average weight $1.7 \pm 0.1 \mathrm{~g}$ ) were distributed in three $40 \mathrm{~L}$ aquaria per treatment (13 fish/aquaria) in a completely randomized design. Over 35 days, the fish received the experimental diets three times daily to apparent satiety. The maximum weight gain, feed efficiency ratio, and protein efficiency ratio were recorded in fish supplemented with 14-15 g/ kg FA. After 28 days, Enterobacteriaceae was registered only in the gut of tilapia without FA augmentation. Gram-negative bacteria in the fish gut decreased $(p<0.05)$ in fish receiving $17 \mathrm{~g} / \mathrm{kg}$ of dietary FA, increased after this level. The intestinal villi height and width were affected $(p<0.05)$ by FA levels and feeding time. Thus, inclusion of $15 \mathrm{~g} / \mathrm{kg}$ of FA was effective in promoting growth, improving intestinal morphometry, and decreasing negative gut bacteria of Nile tilapia juveniles after 35 days.
\end{abstract}

Keywords: fish nutrition; feed additives; growth promoters; sustainable aquaculture; acidifiers

\section{Introduction}

The growth of the aquaculture industry and the consequent intensification of production systems has increased the health challenges for cultivated fish, with direct consequences on their intestinal microbiome, which has an important role in host health and nutritional metabolism [1]. There is increasing pressure for more sustainable aquaculture systems, where the reduction or, preferably, elimination of antibiotics from the production cycle is desired to avoid developing cross-resistance of pathogens to antibiotics and their residues. Thus, the search for alternative feed additives (e.g., pre- and probiotics, essential oils, enzymes, and organic acids) to modulate and improve the gut health of fish has been the focus of researchers in recent years. 
The benefits of dietary supplementation with short-chain organic acids and their salts, also called acidifiers, on growth, feed efficiency, and health of terrestrial livestock, have been evident for decades [2,3]. Acidifiers affect the intestinal tract in two ways: (i) by reducing $\mathrm{pH}$ in the stomach and small intestine, and (ii) by acid dissociation in the bacterial cell and salt anion accumulation that inhibits microbial growth [4]. Despite this, the intensification of studies on organic acids with aquatic animals began only at the end of the 2000-2009 decade [5], although the first study evaluating different acids in fish diets was performed by Rungruangsak and Utne in 1981 [6].

Several studies have reported the benefits of supplementation with various organic acids or their salts in fish diets [7-10], although negative results have also been documented [11-13]. In general, these contradictory reports relate to differences between species and/or rearing conditions [5]. Although Ng and Koh [5] stated that propionic acid, followed by fumaric, formic, and lactic acid, and their salts are the most used in animal feeds, research on fumaric acid in aquafeeds has been limited. To our knowledge, fumaric acid was evaluated only as a single additive in African catfish Claria gariepinus diets $[14,15]$ or as part of dietary organic acid blends for yellow catfish Pelteobagrus fulvidraco [16]. In contrast, fumaric acid is one of the most widely studied organic acids for terrestrial animal feeds, especially pigs [3] and broiler chickens [2].

Fumaric is a weak organic acid with four carbons $\left(\mathrm{C}_{4} \mathrm{H}_{4} \mathrm{O}_{4}\right)$ that is generally stable at room temperature, has a medium solubility in water, and is odorless, nontoxic, and naturally found in plants and fungi [17]. In animal metabolism, fumaric salts are generated during the decomposition of aspartate, phenylalanine, and tyrosine in the ornithine cycle and during purine synthesis. However, when orally ingested or generated from the citric acid cycle, fumaric acid is involved in cellular ATP production [4]. Additionally, fumaric acid has antimicrobial action related to its lipophilic feature and high dissociation capacity (pKa). When crossing the bacterial cellular membrane and reducing the cytoplasmic $\mathrm{pH}$, it alters bacterial metabolism and enzyme activities, inhibiting growth or inducing cell death [18].

Therefore, the aim of this study was to evaluate the dietary supplementation of fumaric acid in aquafeeds based on productive performance, intestinal microbiota effects, and villi morphometry of Nile tilapia (Oreochromis niloticus) juveniles.

\section{Materials and Methods}

\subsection{Experimental Diets}

A basal diet $(350 \mathrm{~g} / \mathrm{kg} \mathrm{CP})$ was formulated and supplemented with fumaric acid at $0,5,10,15,20$, and $30 \mathrm{~g} / \mathrm{kg}$ of diet (Table 1). Fumaric acid (Merck, Germany) was added at the expense of cellulose in a 1:1 ratio. All feedstuffs were ground $(0.8 \mathrm{~mm})$, weighed, mixed, moistened with $250 \mathrm{~g} / \mathrm{kg}$ of distilled water, and pelletized using a meat mincer. Three-millimeter pellets were dried in an air circulation oven at $55{ }^{\circ} \mathrm{C}$ for $24 \mathrm{~h}$. After processing, the pellets were ground and screened to granule sizes proportional to the mouth of the fish. Thereafter, all diets were refrigerated $\left(4-6{ }^{\circ} \mathrm{C}\right)$ throughout the experimental period. The fumaric acid content of all experimental diets was analyzed (Table 2) according to the standard protocol [19]. 
Table 1. Formulation and chemical composition (wet basis) of basal diet.

\begin{tabular}{|c|c|}
\hline Ingredient & Content $(\mathrm{g} / \mathrm{kg})$ \\
\hline Soybean meal & 344.4 \\
\hline Fish meal & 200.0 \\
\hline Corn & 295.4 \\
\hline Corn starch & 100.0 \\
\hline Soybean oil & 20.0 \\
\hline Fumaric acid & 0.00 \\
\hline Cellulose & 30 \\
\hline Vitamin-mineral premix ${ }^{1}$ & 10.0 \\
\hline $\mathrm{BHT}^{2}$ & 0.20 \\
\hline \multicolumn{2}{|l|}{ Analyzed chemical composition } \\
\hline Moisture & 76.6 \\
\hline Crude protein & 353.0 \\
\hline Crude lipid & 115.4 \\
\hline Ash & 81.9 \\
\hline Calcium & 15.5 \\
\hline Phosphorus & 11.2 \\
\hline Digestible energy $(\mathrm{kcal} / \mathrm{g})^{3}$ & 3.4 \\
\hline
\end{tabular}

${ }^{1}$ Guaranteed levels (kg/product): vit. A-1,000,000 IU; vit. D3-312,500 IU; vit. E-18,750 IU; vit. K3-1250 mg; vit. B1 (thiamine) - $2500 \mathrm{mg}$; vit. B2 (riboflavin) - $2500 \mathrm{mg}$; vit. B6 (pyridoxine) $-1875 \mathrm{mg}$; vit. B12—4 mg. vit. C-31,250 mg; nicotinic acid-12,500 mg; calcium pantothenate- $6250 \mathrm{mg}$; biotin-125 mg; folic acid-750 mg; choline $-50,000 \mathrm{mg}$; inositol $-12,500 \mathrm{mg}$; iron sulfate $-6250 \mathrm{mg}$; copper sulfate $-625 \mathrm{mg}$; zinc sulfate $-6250 \mathrm{mg}$; manganese sulfate- $1875 \mathrm{mg}$; sodium selenite $-13 \mathrm{mg}$; calcium iodate $-63 \mathrm{mg}$ and cobalt sulfate $-13 \mathrm{mg}$. ${ }^{2} \mathrm{BHT}=$ butylated hydroxytoluene. ${ }^{3}$ Calculated according to Furuya et al. [20].

Table 2. Fumaric acid content of experimental diets.

\begin{tabular}{ccccccc}
\hline & \multicolumn{7}{c}{ Acid Fumaric Levels (g/kg) } \\
\hline Supplemented & 0 & 5 & 10 & 15 & 20 & 30 \\
Analyzed & 0.43 & 5.6 & 9.1 & 15.7 & 21.2 & 30.5 \\
\hline
\end{tabular}

\subsection{Fish and General Procedures}

Male Nile tilapia juveniles were provided by the Reference Center for Aquaculture and Fishery Resources (Porto Real do Colégio, AL, Brazil) of the Companhia de Desenvolvimento do Vale do São Francisco e Parnaíba (CODEVASF [(São Francisco and Parnaíba Valley Development Company)). Juveniles were fed a commercial diet ( $350 \mathrm{~g} / \mathrm{kg}$ of crude protein) three times daily $(8: 00,12: 00$, and 16:00 h) until apparent satiety for seven days prior to the experiment for acclimation to the experimental conditions. After this period, fish were weighed $(1.7 \pm 0.1 \mathrm{~g})$ and randomly stocked in $40 \mathrm{~L}$ aquaria (13 fish/per tank) in a completely randomized design $(n=3)$. All aquaria had supplementary aeration, temperature control, and biological filters. The aquaria were siphoned daily to remove feces and any uneaten feed, and up to $15 \%$ of the total volume of water was replaced. Tilapia juveniles were fed the experimental diets for 35 days using the same method as described for the acclimation period.

Dissolved oxygen $(6.7 \pm 0.2 \mathrm{mg} / \mathrm{L})$ and water temperature $\left(27.5 \pm 0.3{ }^{\circ} \mathrm{C}\right.$ were monitored daily using a YSI Model $55 \mathrm{~m}$ (YSI Industries, Yellow Springs, OH, USA), and $\mathrm{pH}(7.5 \pm 0.2)$ was monitored with an electronic $\mathrm{pH}$ meter (AK90, AKSO, São Leopoldo, RS, Brazil). Total ammonium $(0.33 \pm 0.123 \mathrm{mg} / \mathrm{L})$ and nitrite $(0.25 \pm 0 \mathrm{mg} / \mathrm{L})$ were evaluated weekly. All water parameters remained within the range considered adequate for Nile tilapia [21].

\subsection{Microbiological and Histological Sampling and Processing}

Weekly (days 7, 14, 21, 28, and 35 of the trial), four fish per treatment were fasted for $24 \mathrm{~h}$, anesthetized by immersion in benzocaine solution $(100 \mathrm{mg} / \mathrm{L})$, and sacrificed by cutting the spinal cord. Each fish was then surface-sterilized with a $70 \%$ ethanol solution to ensure aseptic conditions for necropsy. The abdomen was opened with disinfected 
tools, and the entire intestinal tract was exteriorized. A $3 \mathrm{~cm}$ sample of the proximal intestine was gently rinsed by flushing with a $0.85 \%$ sterile saline solution to remove the digestive content. The sample was then mixed with $1 \mathrm{~mL}$ of $0.85 \%$ sterile saline solution, followed by successive dilutions $\left(10^{-1}\right.$ to $\left.10^{-5}\right)$ in saline solution. A $100 \mu \mathrm{L}$ aliquot was inoculated in duplicate using the spread plate technique. The selective media used were MacConkey agar (Gram-negative) and eosin methylene blue agar (Enterobacteriaceae). Plates were incubated at $30^{\circ} \mathrm{C}$ for $24 \mathrm{~h}$, and colonies were counted using a colony counter. An additional sample of the proximal intestine ( $\pm 1 \mathrm{~cm}$ in length) of each fish was collected for histological analysis. The samples were fixed by immersion in Bouin's solution for $12 \mathrm{~h}$, dehydrated in graded ethanol concentrations, immersed in xylol, and embedded in paraffin wax. After processing, the tissues were sectioned $(5 \mu \mathrm{m})$ and stained with hematoxylin and eosin. The intestine samples were photographed with a Canon PowerShot SX530 HS digital camera coupled to an Olympus Bx 41 microscope. The images were processed and analyzed using ImageJ software. Measurements (height and width of intestinal villi) were performed for all villi observed from three random and non-consecutive fields of each sample.

\subsection{Proximate and Chemical Composition Analyses}

The chemical composition of the experimental diets was determined according to the standard recommendations of the Association of Official Analytical Chemists [19]. Moisture was analyzed by oven-drying samples $\left(105^{\circ} \mathrm{C}\right)$ to constant weight; crude protein was determined using the Kjeldahl method; crude lipid using the Soxhlet method; ash by burning in a muffle furnace at $550{ }^{\circ} \mathrm{C}$ for $24 \mathrm{~h}$; calcium using an atomic absorption spectrophotometer; phosphorus spectrophotometrically using the molybdovanadate method, and fumaric acid by high-performance liquid chromatography (HPLC). All analyses were performed by a certified laboratory (CBO Análises Laboratoriais, Valinhos, São Paulo, Brazil).

\subsection{Calculations and Statistical Procedures}

The following performance parameters were calculated: weight gain (WG = final weight - initial weight $\div$ initial weight $\times 100$ ), feed efficiency ratio (FER $=$ weight gain $(g)$ $\div$ dry feed intake $(\mathrm{g})$ ), and protein efficiency ratio $(\mathrm{PER}=$ weight gain $(\mathrm{g}) \div$ total protein intake).

The data were previously tested for normality (Shapiro-Wilk test) and homoscedasticity of variances (Bartlett's test). Due to the continuous nature of the treatments, a polynomial single and multiple regression analysis was then performed to determine the optimal dietary fumaric acid supplementation level.

\section{Results}

The survival rate during the trial was $100 \%$, and all experimental diets were well accepted by the fish. The dietary fumaric acid level for maximum weight gain (Figure 1a), feed efficiency (Figure 1b), and the protein efficiency ratio (Figure 1c) of Nile tilapia juveniles was estimated to be approximately $14-15 \mathrm{~g} / \mathrm{kg}$. Feed intake in fish was similar $(p>0.05)$ regardless of fumaric acid levels in the diets (Figure 1d).

The interaction between fumaric acid levels and experimental time was significant $(p<0.05)$ for the total intestinal microbiota and villi measurements. The lowest total Gram-negative bacteria was recorded in fish fed with $17 \mathrm{~g} / \mathrm{kg}$ of dietary fumaric acid, as estimated by regression analysis, and showed an increasing trend after this level in the final trial. Gram-negative bacteria decreased in fish fed all diets (Figure 2a). After 28 days of the trial, Enterobacteriaceae was not detected in Nile tilapia fed diets with fumaric acid, while it remained in fish fed the control diet throughout the experimental period (Figure $2 b$ ). 


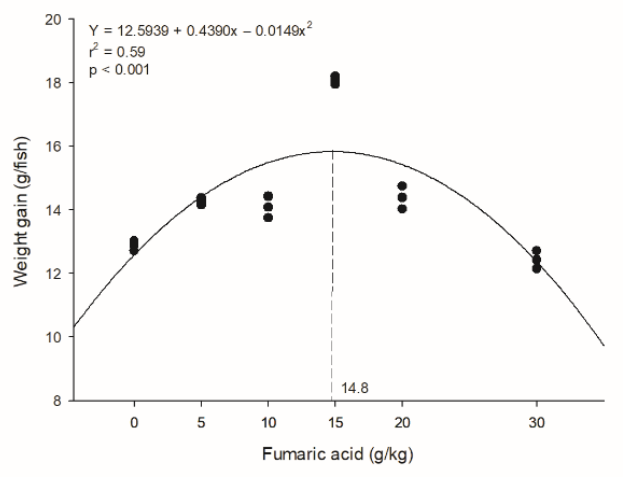

(a)

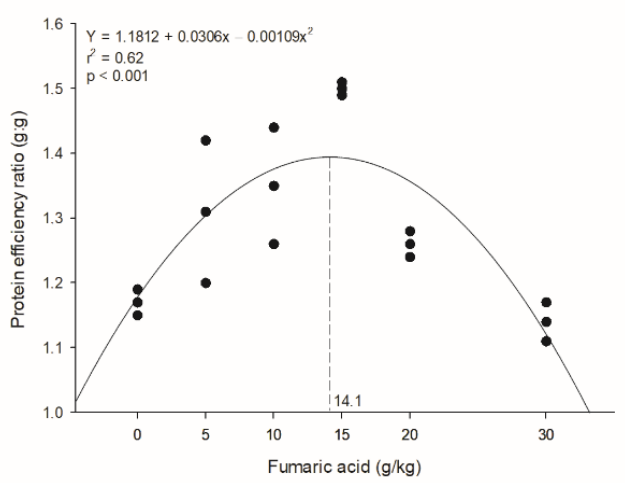

(c)

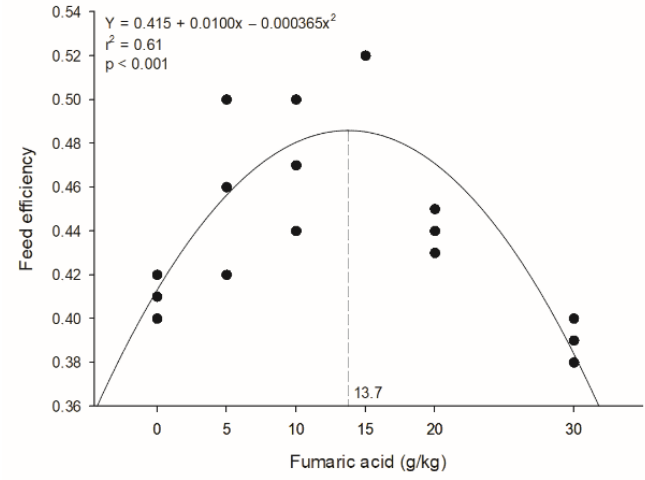

(b)

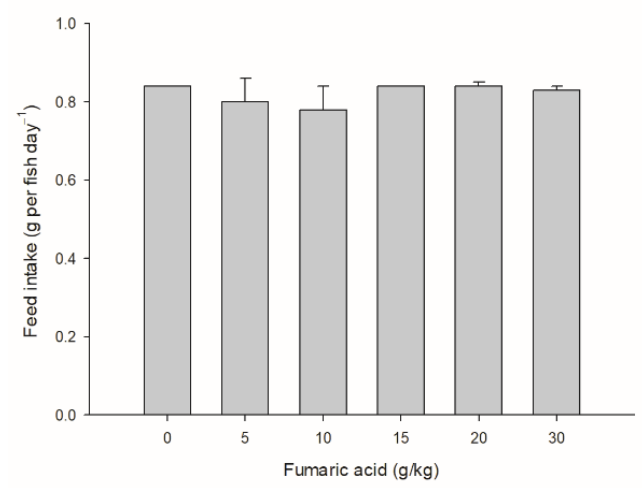

(d)

Figure 1. Relationship between productive performance parameters of Nile tilapia juveniles and dietary fumaric acid levels after 35 days: (a) weight gain; (b) feed efficiency ratio; (c) protein efficiency ratio and (d) feed intake. The dashed line indicates the level of fumaric acid supplementation in Nile tilapia diets for maximum response.

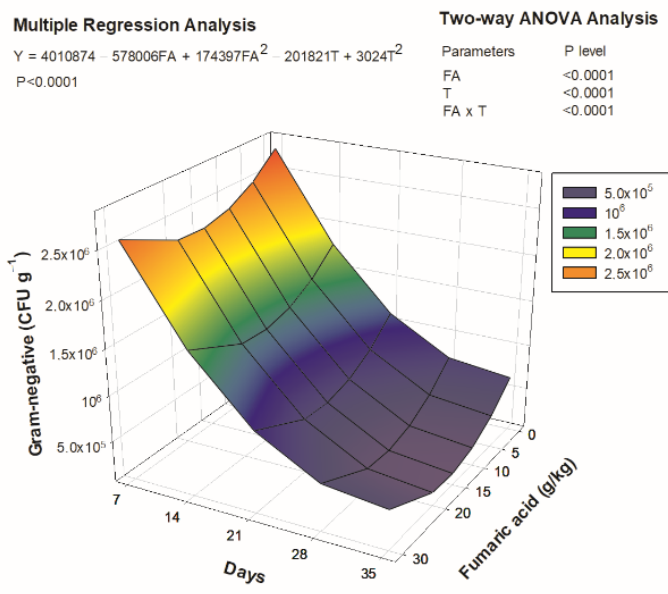

(a)

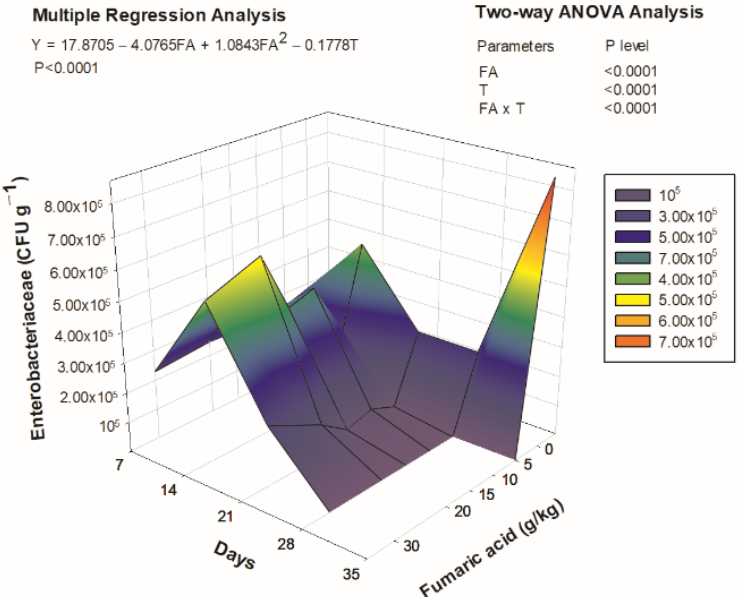

(b)

Figure 2. Relationship between bacteria counts in the gut of Nile tilapia juveniles and dietary fumaric acid levels through 35 days: (a) Gram negative bacteria; (b) Enterobacteriaceae. FA: fumaric acid level (g/kg); T: time (days).

Fumaric acid supplementation up to $11 \mathrm{~g} / \mathrm{kg}$ initially decreased intestinal villi height; however, from this point onwards, the villi increased with fumaric acid supplementation up to $30 \mathrm{~g} / \mathrm{kg}$ until the end of the trial (Figure 3a). In contrast, dietary fumaric acid supplementation decreased the villi width linearly $(p<0.05)$ throughout the trial; the 
maximum values were observed up to 21 days of the experiment, decreasing after this time (Figure 3b). The pictures of intestinal villi of Nile tilapia from each treatment are shown in Figure 4 .

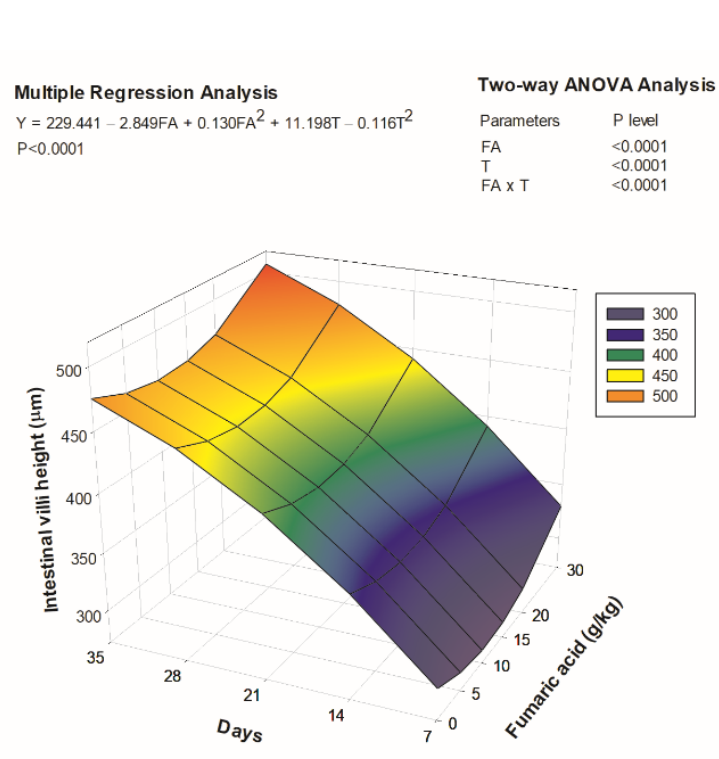

(a)
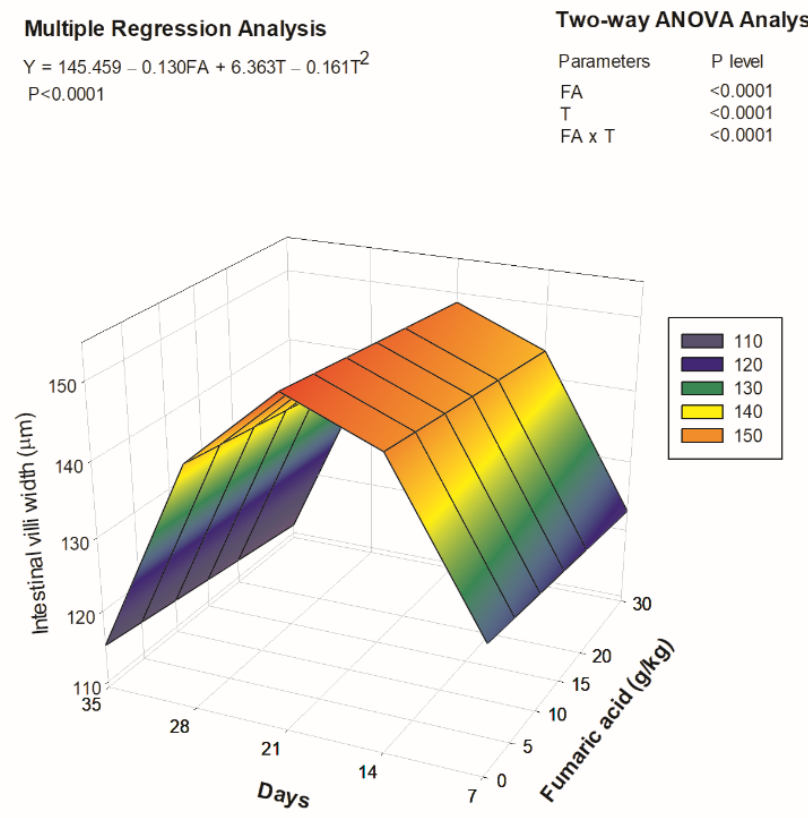

(b)

Figure 3. Relationship between intestinal villi morphometry of Nile tilapia juveniles and dietary fumaric acid levels through 35 days: (a) intestinal villi height; (b) intestinal villi width. FA: fumaric acid level (g/kg); T: time (days).

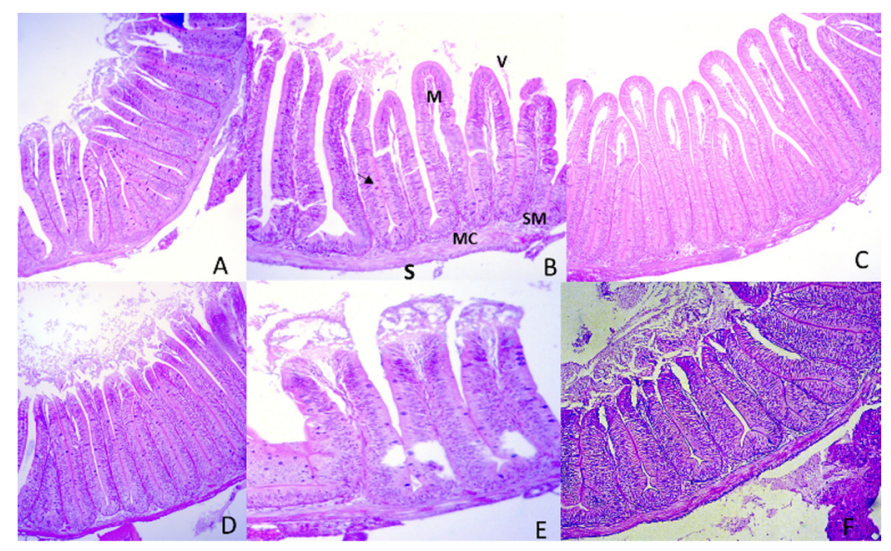

Figure 4. Photomicrograph of proximal intestine of Nile tilapia juveniles fed diets supplemented with fumaric acid levels of $0 \mathrm{~g} / \mathrm{kg}$ (A), $5 \mathrm{~g} / \mathrm{kg}$ (B), $10 \mathrm{~g} / \mathrm{kg}$ (C), $15 \mathrm{~g} / \mathrm{kg}$ (D), $20 \mathrm{~g} / \mathrm{kg}$ (E) and $30 \mathrm{~g} / \mathrm{kg}$ (F). In B, villi (V), mucosal epithelium (M), submucosa layer (SM), muscular layer (MC), serous layer (S) and goblet cell (arrow). HE staining. Bar $=200 \mu \mathrm{m}$.

\section{Discussion}

Growth performance is the key factor in determining the economic benefits of fish production. In the present study, dietary supplementation with fumaric acid clearly improved the growth performance, feed efficiency, and protein efficiency ratio of Nile tilapia juveniles. The greatest difference was found for weight gain, with values increasing proportionally to fumaric acid supplementation of up to $14-15 \mathrm{~g} / \mathrm{kg}$, followed by a reduction thereafter. Previously, only Omosowone et al. [14] reported an improvement in growth, feed efficiency, and protein efficiency ratio of African catfish juveniles fed up to $1 \mathrm{~g} / \mathrm{kg}$ fumaric acid diets. 
After eight weeks, $0.5 \mathrm{~g} / \mathrm{kg}$ of malic acid diets increased weight gain and feed efficiency of Nile tilapia, but no additional gains in fish were recorded with up to $8 \mathrm{~g} / \mathrm{kg}$ of supplementation with that acid [22]. The benefits of dietary supplementation of several organic acids in a pure form, such as salts or blends in aquafeeds, have been reported for many fish species [5]. These gains are usually a result of a complex group of factors such as the $\mathrm{pH}$ reduction in the gastrointestinal tract favoring the activity of digestive enzymes [6], and consequently the digestibility of nutrients [10]; antimicrobial activity of organic acids; and protective effects on intestinal epithelium, regardless of the intrinsic properties of the organic acid evaluated [23]. This indicates that it is necessary to determine the optimum dietary supplementation levels of fumaric acid for different fish species to maximize the benefits of this feed additive.

Dietary supplementation greater than $15 \mathrm{~g} / \mathrm{kg}$ of fumaric acid tended to decrease productive performance as well as feed and protein use of Nile tilapia juveniles. This decrease in growth, feed, and protein use was also observed in African catfish fed diets with greater than $10 \mathrm{~g} / \mathrm{kg}$ of fumaric acid [14]. The negative impact of organic acid supplementation on fish growth can be attributed to a reduction in feed intake due to acidification of diets, which renders them less palatable [24]. However, the feed intake of fumaric acid diets by Nile tilapia was similar to that of the non-supplemented diet, despite fumaric acid having a tart flavor [17]. In fact, tilapia has been shown to be able to adjust the ingestion of diets with a high range of supplementation of several organic acids or their salts, such as malic [9] and potassium diformate [12].

Fumaric acid originates mainly from the oxidation of succinate and is converted to malic acid in the tricarboxylic acid cycle. In pigs, fumaric acid is an energy source readily available for use by the intestinal mucosa, promoting a faster recovery of gastrointestinal cells and increased absorptive surface of the gut [3]. This is a plausible hypothesis to explain the increase in the height and width of intestinal villi in Nile tilapia fed fumaric acidsupplemented diets. Nile tilapia juveniles given malic acid supplemented diets showed higher whole body, muscle, and liver lipids, a common response to increased availability of dietary energy [25]. Additionally, the antimicrobial activity of organic acids favors the development of non-pathogenic microorganisms, forming a protective barrier that assists in the development of the villi and enables greater absorption and utilization of nutrients; thus, the improvement of growth, feed, and protein use in Nile tilapia is a result of a multifactorial set of benefits provided by fumaric acid supplementation.

Positive results of fumaric acid-supplemented diets up to $15 \mathrm{~g} / \mathrm{kg}$ are clearly shown in the present study. However, higher inclusion levels of this organic acid led to decreased performance parameters in Nile tilapia juveniles. The effects of overdoses of organic acids $(>10 \mathrm{~g} / \mathrm{kg})$ in aquafeeds have rarely been studied, and deserve further research. For example, clinical signs of liver damage (necrosis, sinusoid disorganization, and hemorrhage) were more apparent in Nile tilapia fingerlings fed sodium citrate-supplemented diets (20 and $40 \mathrm{~g} / \mathrm{kg}$ ), as were decreased growth and feed efficiency [13]. In the present study, the height and width of intestinal villi slightly decreased with fumaric acid supplementation, and increased when more than $11 \mathrm{~g} / \mathrm{kg}$ fumaric acid was added. Huan et al. [10] also registered an increase in villi height of Nile tilapia diets with $0.9 \mathrm{~g} / \mathrm{kg}$ of a microencapsulated organic acid salt blend. The positive effects of organic acid blends on villi morphometry can be potentiated when associated with other substances, such as essential oils [8]. However, intestinal villi height and width were similar between Nile tilapia fed diets supplemented with or without organic acids [10]. Omosowone et al. [15] reported a slight loss of intestinal microvilli and desquamation of the mucosal epithelium of African catfish fed 10 and $15 \mathrm{~g} / \mathrm{kg}$ of fumaric acid. Moreover, the same authors identified anaplasia and necrosis in the intestinal villi of C. gariepinus fed diets with a $20 \mathrm{~g} / \mathrm{kg}$ concentration. Additionally, there was a decrease in the width of villi of fish after 21 days of fumaric acid supplementation. Despite this, no pathological signs were observed in the intestinal villi of Nile tilapia regardless of fumaric acid supplementation in the present study. 
The antimicrobial effectiveness of organic acids depends on the dissociation constant (pKa), with higher values indicating greater effectiveness. Fumaric acid has a high dissociation potential, with values between 3.02 and 4.76 [5], enabling it to cross the bacterial cell membrane. In the specific case of Gram-negative bacteria, this effect is enhanced due to the thin cellular wall formed by a single layer or few layers of glycan-peptide and an outer membrane separated by the periplasmatic space [26].

Colonization and establishment constitute a complex process that depends on factors such as the microbial composition of the water, the diet provided, development stage, stress level, and the environment. This occurs because the intestine has a wide variety of aerobic and anaerobic microorganisms [27-30], which would explain the late colonization observed in the present study.

The literature offers few studies involving diets supplemented with organic acids, particularly fumaric acid, and the evaluation of the bacterial community in the gastrointestinal tract of tilapia. In vitro trials reported that the use of certain organic acids, such as formic, acetic, propionic, and butyric, inhibited the growth of the pathogenic Vibrio harveyi, with the strongest inhibitory effect achieved with formic acid [31].

Among the bacterial agents in aquatic ecosystems, Gram-negative Enterobacteriaceae can be found in the skin, gills, and intestines of fish [31]. Some species, such as Enterobacter spp., Klebsiella spp., Escherichia coli, Proteus spp., Serratia marcescens, Salmonella spp. and Citrobacter spp., [31] are important opportunistic pathogens that can cause intestinal disease [32-34]. In the present study, the addition of fumaric acid to the diet inhibited the growth of enterobacteria in the intestine beginning on Day 28, independent of the supplementation level, thereby constituting a viable strategy for the exclusion of potentially pathogenic bacteria from the animal microbiota.

Hybrid tilapia fed a diet supplemented with potassium diformate at a proportion of $0.6 \%$ exhibited an increase in weight gain as well as a change in the intestinal bacterial community [12]. Kluge et al. [35] also investigated the gastrointestinal microflora of piglets for a period of 35 days and found a reduction in total aerobic and anaerobic bacteria as well as lactic acid-producing and Gram-negative bacteria.

\section{Conclusions}

Dietary inclusion of $15 \mathrm{~g} / \mathrm{kg}$ of fumaric acid improved growth performance and proved to be effective in reducing intestinal Gram-negative bacteria in Nile tilapia juveniles after 35 days.

Author Contributions: Conceptualization, S.M.B.C.d.S. and Á.J.A.B.; methodology, S.M.B.C.d.S., A.L.S., L.C.R.d.S. and Á.J.A.B.; formal analysis, Á.J.A.B., A.L.S. and L.C.R.d.S.; investigation, S.C.V.d.N. and G.K.A.C.; resources, S.M.B.C.d.S., E.S.C. and Á.J.A.B.; data curation, S.C.V.d.N. and G.K.A.C.; S.M.B.C.d.S. and Á.J.A.B.; writing—original draft preparation, S.C.V.d.N., S.M.B.C.d.S., Á.J.A.B., A.L.S. and L.C.R.d.S.; writing-review and editing, S.M.B.C.d.S. and Á.J.A.B.; supervision, S.M.B.C.d.S. and Á.J.A.B.; project administration, S.M.B.C.d.S. and Á.J.A.B.; funding acquisition, S.M.B.C.d.S. and Á.J.A.B. All authors have read and agreed to the published version of the manuscript.

Funding: The authors thank the Fundação de Amparo a Ciência e Tecnologia do Estado de Pernambuco for Master scholarships granted to S.C.V.N. (Process no. IBPG-0736-5.06/15).

Institutional Review Board Statement: This study was conducted in accordance with the ethical principles of experimentation and followed protocols authorized by the Ethics Committee on the Use of Animals of the Federal Rural University of Pernambuco, Brazil (License no. 08/2017).

Data Availability Statement: The datasets generated during and analyzed during the current study are available from the corresponding author upon reasonable request.

Conflicts of Interest: The authors declare no conflict of interest. 


\section{References}

1. Butt, R.L.; Volkoff, H. Gut Microbiota and Energy Homeostasis in Fish. Front. Endocrinol. 2019, 10, 9. [CrossRef]

2. Huyghebaert, G.; Ducatelle, R.; Van Immerseel, F. An update on alternatives to antimicrobial growth promoters for broilers. Vet. J. 2011, 187, 182-188. [CrossRef] [PubMed]

3. Suiryanrayna, M.V.A.N.; Ramana, J.V. A review of the effects of dietary organic acids fed to swine. J. Anim. Sci. Biotechnol. 2015, 6 , 45. [CrossRef] [PubMed]

4. Freitag, M. Organic acids and salts promote performance and health in animal husbandry. In Acidifiers in Animal Nutrition: A Guide for Feed Preservation and Acidification to Promote Animal Performance; Lückstädt, C., Ed.; Nottinghan University Press: Nottingham, UK, 2009; pp. 1-12.

5. Ng, W.-K.; Koh, C.-B. The utilization and mode of action of organic acids in the feeds of cultured aquatic animals. Rev. Aquac. 2016, 9, 342-368. [CrossRef]

6. Rungruangsak, K.; Utne, F. Effect of different acidified wet feeds on protease activities in the digestive tract and on growth rate of rainbow trout (Salmo gairdneri Richardson). Aquaculture 1981, 22, 67-79. [CrossRef]

7. Abdel-Tawwab, M.; Khattaby, A.E.-R.; Monier, M.N. Dietary acidifiers blend enhanced the production of Nile tilapia (Oreochromis niloticus), striped mullet (Mugil cephalus), and African catfish (Clarias gariepinus) polycultured in earthen ponds. Aquac. Int. 2019, 27, 369-379. [CrossRef]

8. Addam, K.G.S.; Pereira, S.A.; Jesus, G.F.A.; Cardoso, L.; Syracuse, N.; Lopes, G.R.; Lehmann, N.B.; da Silva, B.C.; de Sá, L.S.; Chaves, F.C.M.; et al. Dietary organic acids blend alone or in combination with an essential oil on the survival, growth, gut/liver structure and de hemato-immunological in Nile tilapia Oreochromis niloticus. Aquac. Res. 2019, 50, 2960-2971. [CrossRef]

9. Hassaan, M.S.; Soltan, M.A.; Jarmołowicz, S.; Abdo, H.S. Combined effects of dietary malic acid and Bacillus subtilison growth, gut microbiota and blood parameters of Nile tilapia (Oreochromis niloticus). Aquac. Nutr. 2018, 24, 83-93. [CrossRef]

10. Huan, D.; Li, X.; Chowdhury, M.A.K.; Yang, H.; Liang, G.; Leng, X. Organic acid salts, protease and their combination in fish meal-free diets improved growth, nutrient retention and digestibility of tilapia (Oreochromis niloticus $\times$ O. aureus). Aquac. Nutr. 2018, 24, 1813-1821. [CrossRef]

11. Vielma, J.; Ruohonen, K.; Lall, S.P. Supplemental citric acid and particle size of fish bone-meal influence the availability of minerals in rainbow trout Oncorhynchus mykiss (Walbaum). Aquac. Nutr. 1999, 5, 65-71. [CrossRef]

12. Zhou, Z.; Liu, Y.; He, S.; Shi, P.; Gao, X.; Yao, B.; Ringø, E. Effects of dietary potassium diformate (KDF) on growth performance, feed conversion and intestinal bacterial community of hybrid tilapia (Oreochromis niloticus $\$ \times$ O. aureus $\sigma^{7}$ ). Aquaculture 2009, 291, 89-94. [CrossRef]

13. Romano, N.; Simon, W.; Ebrahimi, M.; Fadel, A.H.; Chong, C.M.; Kamarudin, M.S. Dietary sodium citrate improved oxidative stability in red hybrid tilapia (Oreochromis sp.) but reduced growth, health status, intestinal short chain fatty acids and induced liver damage. Aquaculture 2016, 458, 170-176. [CrossRef]

14. Omosowone, O.; Dada, A.; Adeparusi, E. EFFECTS OF DIETARY SUPPLEMENTATION OF FUMARIC ACID ON GROWTH PERFORMANCE OF AFRICAN CATFISH Clarias gariepinus AND Aeromonas sobria CHALLENGE. Croat. J. Fish. 2015, 73, 13-19. [CrossRef]

15. Omosowone, O.O.; Dada, A.A.; Adeparusi, E.O. Histological alterations in some organs of African catfish fed with fumaric acid supplemented diets. Int. J. Ecol. Environ. Stud. 2015, 3, 85-92.

16. Zhu, Y.; Qiu, X.; Ding, Q.; Duan, M.; Wang, C. Combined effects of dietary phytase and organic acid on growth and phosphorus utilization of juvenile yellow catfish Pelteobagrus fulvidraco. Aquaculture 2014, 430, 1-8. [CrossRef]

17. Partanen, K.H.; Mroz, Z. Organic acids for performance enhancement in pig diets. Nutr. Res. Rev. 1999, 12, 117-145. [CrossRef]

18. Hanczakowska, E.; Szewczyk, A.; Okon, K. Caprylic, capric and/or fumaric acids as antibiotic replacements in piglet feed. Ann. Anim. Sci. 2011, 11, 115-124.

19. Association of Official Analytical Chemists-AOAC. Official Methods of Analysis; Helrich, K., Ed.; Association of Official Analytical Chemists, Inc.: Arlington, VA, USA, 1990; Volume 1.

20. Furuya, W.M.; Pezzato, L.E.; Barros, M.M.; Boscolo, W.R.; Cyrino, J.E.P.; Furuya, V.R.B.; Feiden, A. Tabelas Brasileiras Para A Nutrição de Tilápías; Furuya, W.M., Ed.; GFM: Toledo, PR, Brazil, 2010; ISBN 9788560308149.

21. El-Sayed, A.-F.M. Tilapia Culture; CABI Publishing: Oxfordshire, UK, 2006; ISBN 9780851990149.

22. Chen, Y.J.; Luo, L.; Zhang, G.Z.; Li, Z.; Bai, F.J.; Shi, Y.Q.; Yang, H.S. Effect of dietary L-malic acid supplementation on growth, feed utilization and digestive function of juvenile GIFT tilapia Oreochromis niloticus (Linnaeus, 1758). J. Appl. Ichthyol. 2016, 32, 1118-1123. [CrossRef]

23. Shah, S.Z.H.; Afzal, M.; Khan, S.Y.; Hussain, S.M.; Habib, R.Z. Prospects of using citric acid as fish feed supplement. Int. J. Agric. Biol. 2015, 17, 1-8.

24. Xie, S.; Zhang, L.; Wang, D. Effects of several organic acids on the feeding behavior of Tilapia nilotica. J. Appl. Ichthyol. 2003, 19, 255-257. [CrossRef]

25. Chen, Y.-J.; Zhang, T.-Y.; Luo, L.; Shi, Y.-Q.; Bai, F.-J.; Jiang, D.-N. Impact of Dietary L-Malic Acid Supplementation on Growth, Feed Utilization, Ash Deposition, and Hepatic Lipid Metabolism of Juvenile Genetically Improved Farmed Tilapia, Oreochromis niloticus. J. World Aquac. Soc. 2016, 48, 563-573. [CrossRef]

26. Prescott, L.M.; Harley, P.J.; Donald, A.K. Microbiology; The Macgraw-Hill Companies: Boston, MA, USA, 2002. 
27. Korsnes, K.; Nicolaisen, O.; Skår, C.K.; Nerland, A.H.; Bergh, Ø. Bacteria in the gut of juvenile cod Gadus morhua fed live feed enriched with four different commercial diets. ICES J. Mar. Sci. 2006, 63, 296-301. [CrossRef]

28. Nayak, S.K. Role of gastrointestinal microbiota in fish. Aquac. Res. 2010, 41, 1553-1573. [CrossRef]

29. Fjellheim, A.J.; Playfoot, K.J.; Skjermo, J.; Vadstein, O. Vibrionaceae dominates the microflora antagonistic towards Listonella anguillarum in the intestine of cultured Atlantic cod (Gadus morhua L.) larvae. Aquaculture 2007, 269, 98-106. [CrossRef]

30. Ringø, E.; Sperstad, S.; Myklebust, R.; Refstie, S.; Krogdahl, $\AA$. Characterisation of the microbiota associated with intestine of Atlantic cod (Gadus morhua L.). Aquaculture 2006, 261, 829-841. [CrossRef]

31. Mine, S.; Boopathy, R. Effect of Organic Acids on Shrimp Pathogen, Vibrio harveyi. Curr. Microbiol. 2011, 63, 1-7. [CrossRef] [PubMed]

32. Freney, J.; Husson, M.O.; Gavini, F.; Madier, S.; Martra, A.; Izard, D.; Leclerc, H.; Fleurette, J. Susceptibilities to antibiotics and antiseptics of new species of the family Enterobacteriaceae. Antimicrob. Agents Chemother. 1988, 32, 873-876. [CrossRef] [PubMed]

33. Sabat, G.; Rose, P.; Hickey, W.J.; Harkin, J.M. Selective and Sensitive Method for PCR Amplification of Escherichia coli 16S rRNA Genes in Soil. Appl. Environ. Microbiol. 2000, 66, 844-849. [CrossRef]

34. Stone, N.D.; O'Hara, C.M.; Williams, P.P.; McGowan, J.E.; Tenover, F.C. Comparison of Disk Diffusion, VITEK 2, and Broth Microdilution Antimicrobial Susceptibility Test Results for Unusual Species of Enterobacteriaceae. J. Clin. Microbiol. 2007, 45, 340-346. [CrossRef]

35. Kluge, H.; Broz, J.; Eder, K. Effect of benzoic acid on growth performance, nutrient digestibility, nitrogen balance, gastrointestinal microflora and parameters of microbial metabolism in piglets. J. Anim. Physiol. Anim. Nutr. 2006, 90, 316-324. [CrossRef] [PubMed] 